\title{
Mantle-Derived Helium Emission near the Pohang EGS Site, South Korea: Implications for Active Fault Distribution
}

\author{
Heejun Kim, ${ }^{1}$ Hyunwoo Lee ${ }^{1 D},{ }^{1}$ Jaemin Lee, ${ }^{2,3}$ Hyun A. Lee, ${ }^{2}$ Nam Chil Woo, ${ }^{2}$ Youn-Soo Lee, ${ }^{4}$ \\ Takanori Kagoshima, ${ }^{5}$ Naoto Takahata, ${ }^{5}$ and Yuji Sano ${ }^{5,6}$ \\ ${ }^{1}$ School of Earth and Environmental Sciences, Seoul National University, Seoul 08826, Republic of Korea \\ ${ }^{2}$ Department of Earth System Sciences, Yonsei University, Seoul 03722, Republic of Korea \\ ${ }^{3}$ Korea Institute of Geoscience and Mineral Resources, Daejeon 34132, Republic of Korea \\ ${ }^{4}$ Division of Environmental Science and Engineering, Pohang University of Science and Technology, Pohang 37673, Republic of Korea \\ ${ }^{5}$ Atmosphere and Ocean Research Institute, University of Tokyo, Kashiwa, Chiba 277-8564, Japan \\ ${ }^{6}$ Institute of Surface-Earth System Science, Tianjin University, Tianjin 300072, China \\ Correspondence should be addressed to Hyunwoo Lee; lhw615@snu.ac.kr
}

Received 18 February 2020; Revised 3 July 2020; Accepted 6 July 2020; Published 24 July 2020

Academic Editor: Ondra Sracek

Copyright (C) 2020 Heejun Kim et al. This is an open access article distributed under the Creative Commons Attribution License, which permits unrestricted use, distribution, and reproduction in any medium, provided the original work is properly cited.

\begin{abstract}
An Mw 5.5 earthquake occurred in Pohang, South Korea on November 15, 2017, resulting in a great impact on society. Despite a lot of controversy about the cause of the earthquake in relation to the enhanced geothermal system (EGS), the location of earthquakerelated active faults is poorly known. Here, we first report the results of the geochemical and isotopic analyses of dissolved gases in groundwater in the Heunghae, Yeonil, and Sinkwang areas. According to the $\mathrm{N}_{2}$-Ar-He relationship, samples from the Heunghae and Yeonil areas are contributed to the mantle, except for the Sinkwang area, where all samples are atmospheric. The Pohang samples consist mainly of $\mathrm{N}_{2}$ and $\mathrm{CO}_{2}$, and some samples of the Heunghae and Yeonil areas contain substantial $\mathrm{CH}_{4}$. Stable isotope compositions of $\mathrm{N}_{2}\left(\delta^{15} \mathrm{~N}=0.2\right.$ to $\left.3.6 \%\right), \mathrm{CO}_{2}\left(\delta^{13} \mathrm{C}=-27.3\right.$ to $\left.-16.0 \%\right)$, and $\mathrm{CH}_{4}\left(\delta^{13} \mathrm{C}=-76.1\right.$ to $\left.-70.0 \%\right)$ indicate that these components are derived from organic substances in sedimentary layer of Pohang Basin. On the other hand, helium isotope ratios $\left({ }^{3} \mathrm{He} /{ }^{4} \mathrm{He}\right.$, up to $\left.3.83 \mathrm{Ra}\right)$ represent the significant mantle contribution in the Heunghae and Yeonil areas. Through the distribution of high ${ }^{3} \mathrm{He} /{ }^{4} \mathrm{He}$ ratios, we propose that the Heunghae, Namsong, and Jamyeong faults are the passage of mantle-derived fluids. Computed ${ }^{3} \mathrm{He}$ fluxes of the Heunghae (120 to 3,000 atoms $\mathrm{cm}^{-2} \mathrm{sec}^{-1}$ ), Namsong (52 to 1,300 atoms $\mathrm{cm}^{-2} \mathrm{sec}^{-1}$ ), and Jamyeong (83 to 2,100 atoms $\mathrm{cm}^{-2} \mathrm{sec}^{-1}$ ) faults are comparable to other major active faults around the world, reflecting either high porosity or high helium flow rates. Therefore, our results demonstrate that there are active faults near the EGS facilities, which can provide the basis for future studies.
\end{abstract}

\section{Introduction}

Enhanced geothermal system (EGS) is a type of heat exchanger designed to improve the efficiency of geothermal energy plants. EGS is configured to enable convective production or to improve heat production. One of the main goals of EGS is to increase the permeability of reservoir rocks with high temperatures but low permeability. For this purpose, hydraulic fracturing, fluid injection (and/or extraction), and acidification can be used [1].

The correlation between EGS and seismic activity has been proposed for decades [1]. Geysers (USA), Cooper Basin
(Australia), Berlin (El Salvador), Soultz-Sous-Forêts (France), and Basel (Switzerland) are well-known examples of EGS-related earthquake activities. In addition to these cases at the EGS site, for other cases such as wastewater injection, carbon capture and storage (CCS), or hydrocarbon (e.g., shale gas and oil) extraction, fluid injection, and hydraulic fracturing are often proposed as triggers of earthquakes (e.g., Keranen et al. [2]). Two mechanisms for triggering earthquakes associated with fluid injection and/or extraction are described by McGarr et al. [3]; (1) direct fluid pressure effects on injection and (2) changes in solid stress due to fluid extraction and/or injection. As we can infer from 
earthquake-inducing mechanisms of fluid injection, knowing locations of faults around the EGS site is important for society. For both cases, it is necessary to identify not only faults beneath the EGS site but also any potentially unknown faults. In the case of the 2019 Ridgecrest earthquake, for example, it shows how the earthquake swarm can propagate to interlocked faults [4]. This refers to the possibilities that the small induced earthquake can trigger much larger seismicity than expected, which amplifies the seismic hazards and risks around the EGS site.

Since mantle-derived fluids have been identified and quantified from the San Andreas Fault system [5] in the nonvolcanic region, noble gas studies have been conducted in several active fault zones to understand the fluid behavior related to seismicity (e.g., Sano et al. [6]). Even in some cases, helium isotope ratio distribution could detect concealed fault zones [7]. Noble gases and their isotope compositions can be used as natural tracers. They are chemically inert, retaining their properties through the water-rock systems. Therefore, the contents and isotopic compositions of noble gases allow us to trace the fluid sources into mantle, crust, and atmosphere. It is also possible to quantify the contribution of each source [8]. Mantle-derived helium and $\mathrm{CO}_{2}$ degassing through faults in the southeastern Korean peninsula has recently been reported [9].

Here, we report new chemical and isotopic compositions of dissolved gases in groundwater, which are rarely been documented in the study area. Then, we will first discuss the general characteristics of gas compositions in this area. Based on the results, the perceptual impact on the composition of the noble gas is assessed to suggest that there are active fault zones near the EGS site, reaching the upper mantle through continental crust. In addition, helium flux through faults was calculated and compared with the characteristics of major fault zones around the world.

1.1. Geological Setting. The Pohang region consists of three subdivisions: Heunghae, Yeonil, and Sinkwang areas (Figure 1). The Heunghae and Yeonil areas are located in Pohang Basin, the Miocene sedimentary basin, and the Sinkwang area is near the Yangsan fault (Figure 1). Pohang Basin is one of the largest sedimentary basins in the Korean Peninsula [10]. The border faults in Pohang Basin are the Yeonil tectonic line, the Ocheon fault system, and segmented faults bounding to the west (Figure 1). These western boundary segment faults are almost parallel to the Yangsan fault, 2$7 \mathrm{~km}$ away from the west. During the early Miocene period, Pohang Basin was formed while the East Sea (Sea of Japan) which is a back-arc basin was opened, and the opening was ceased at $\sim 15 \mathrm{Ma}[11,12]$. The sedimentation in the Pohang Basin lasted from 17 to $10 \mathrm{Ma}[11,12]$. The basin is filled with Paleogene volcanic rocks and granite, followed by Neogene conglomerates, sandstone, and mudstone, with a total thickness of less than $500 \mathrm{~m}[13,14]$. The basin has been cut by normal faults with the NNE-SSW strike and eastern dip. These normal faults have been formed after $15 \mathrm{Ma}$, blocked by other normal faults with the ENE-WSW strike [14]. The Sinkwang area is spread over Cretaceous biotite granite cut by the Yangsan fault covered with quaternary sediments
(Figure 1, [14]). The Yangsan fault, located at the current Cretaceous sedimentary area, is a strike-slip fault formed in the early Cretaceous period as a result of tension due to the subduction of the Izanagi plate $[15,16]$. After the subduction of the Pacific plate in the late Cretaceous period, compressive stresses affected the Yangsan fault. The direction of compressive stress was initially in the NW-SE direction at the end of the Cretaceous period, and the direction of subduction at the end of the Paleogene changed and moved in the NE-SW direction $[15,16]$.

1.2. 2017 Pohang Earthquake. The Pohang enhanced geothermal system (EGS) project was launched in November 2010 to produce $160^{\circ} \mathrm{C}$ geothermal water and $1.2 \mathrm{MW}$ geothermal energy in a nonvolcanic area [17]. To construct the EGS facility, two boreholes (PX-1 and PX-2) were drilled through the sedimentary basin into the granodiorite basement rock. The measuring depths of the two boreholes (MD, measured along the borehole) are $4,362 \mathrm{~m}$ and 4,382 m, respectively. Hydraulic fracturing and fluid injection were performed from January 2016 to September 2017 to increase geothermal productivity [17]. During this period, five hydraulic stimuli were performed through PX-1 and PX2. First, the third and fifth hydraulic stimuli were performed on the PX-2 with maximum well-head pressures of $89.2 \mathrm{MPa}$, 88.8 $\mathrm{MPa}$, and 84.6 $\mathrm{MPa}$, respectively. The second and fourth hydraulic stimuli were performed on the PX-1, and the maximum well-head pressures were 27.71 $\mathrm{MPa}$ and 25.16 MPa, respectively.

After the third hydraulic stimulation, an earthquake occurred with Mw 3.2. About two months after the cessation of the fifth hydraulic stimulus, on November 15, 2017, an earthquake with Mw 5.5 occurred (Figure 1), followed by more than one hundred aftershocks ( $\geq$ Mw 2.0). The earthquake was the second-largest earthquake in the Korean Peninsula since modern earthquake observation has begun in 1978 , resulting in physical and economic damage to local residents (135 people were injured and more than 1,700 people were in emergency housing; directly USD $75 \mathrm{M}$ and total economic impact USD $300 \mathrm{M}$ ) [17]. Due to this great impact on Korean society, it is necessary to study active faults related to potential seismic crises in this area.

\section{Methods}

We collected groundwater samples from groundwater wells in the Heunghae, Yeonil, and Sinkwang areas, Pohang, Republic of Korea (Table 1, Figure 1). Ranges of water temperatures and $\mathrm{pH}$ are 14.3 to $20.5^{\circ} \mathrm{C}$ and 6.0 to 9.0 , respectively, and well depth ranges between 30 and $230 \mathrm{~m}$ from the topographic surface. The samples were stored in copper tubes and sealed with clamps, except for PH-3 that was collected in a preevacuated Giggenbach bottle. Dissolved gases were extracted from water samples by the high vacuum system and analyzed in the Atmosphere and Ocean Research Institute (AORI), the University of Tokyo. Concentrations (consist of $\mathrm{CO}_{2}, \mathrm{~N}_{2}, \mathrm{O}_{2}$, $\mathrm{CH}_{4}, \mathrm{Ar}$, and $\mathrm{He}$ ) of dissolved gases were measured by a Pfeiffer QMS 200 quadrupole mass spectrometer (QMS). 


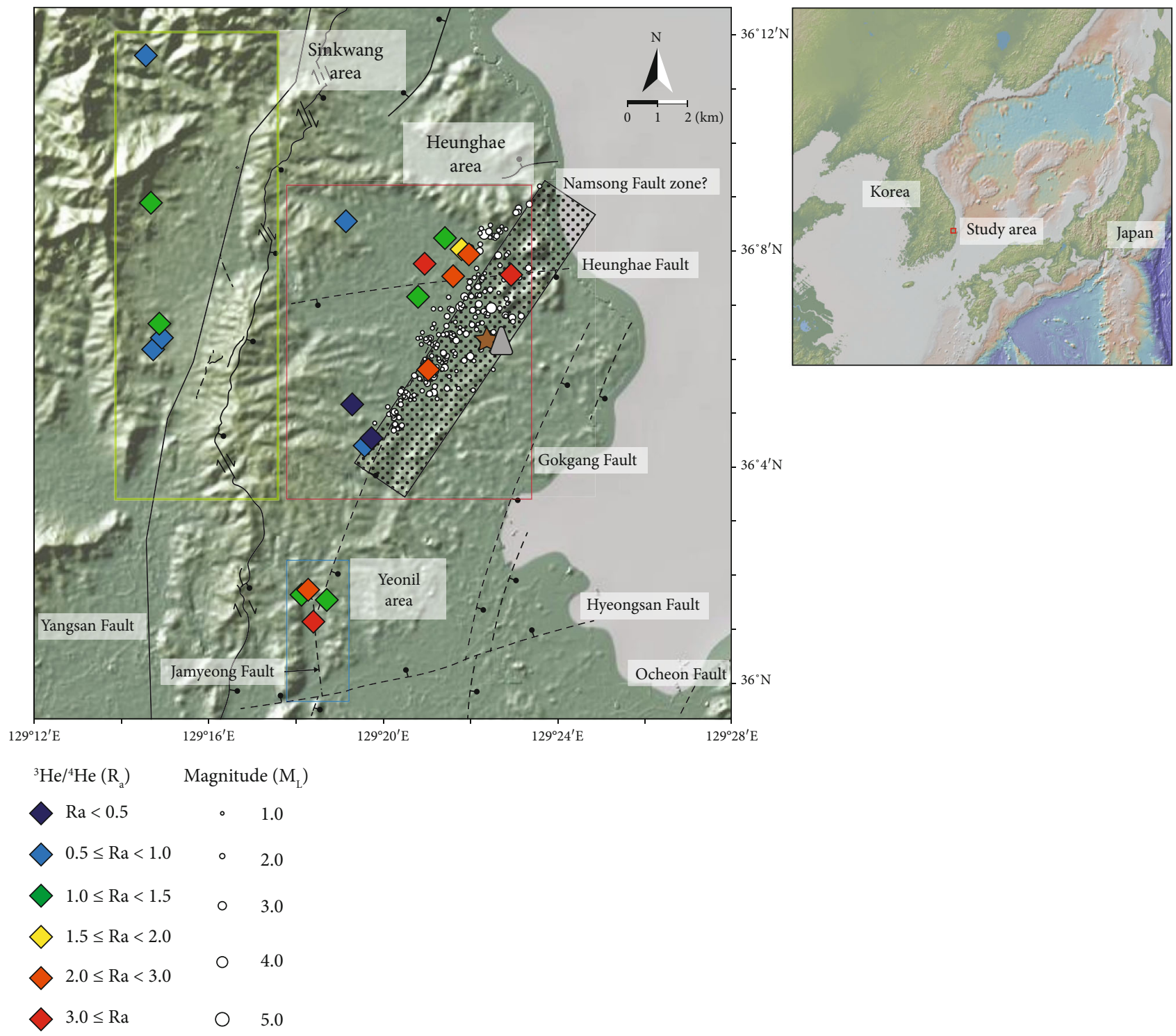

Figure 1: Geological map of Pohang, South Korea (modified from Song [14]), created by GeoMapApp 3. 6. 10 [52]. Sample locations are marked with diamond symbols. Each symbol is represented by a helium isotope ratio $\left({ }^{3} \mathrm{He} /{ }^{4} \mathrm{He}\right)$. The location and scale (white circle) of aftershocks until 2017 are excerpts from the 2017 annual report of earthquakes published by the Korea Meteorological Agency (KMA). The gray triangle represents the EGS site, and the brown star stands for the epicenter of the Mw 5.5 earthquake that occurred on November 15, 2017.

Stable isotope compositions of nitrogen for $\mathrm{N}_{2}$ and carbon for $\mathrm{CO}_{2}$ and $\mathrm{CH}_{4}$ were measured by an isotope ratio mass spectrometer (Isoprime 100 by Elementar). For samples with high $\mathrm{CH}_{4}$ concentration (>4\%), coexisting $\mathrm{CO}_{2}$ and $\mathrm{CH}_{4}$ were separated before measurement by liquid nitrogen. To measure ${ }^{3} \mathrm{He} /{ }^{4} \mathrm{He}$ and ${ }^{4} \mathrm{He} /{ }^{20} \mathrm{Ne}$ ratios, dissolved gas samples were purified by titanium getters at $400^{\circ} \mathrm{C}$ and charcoal traps at liquid nitrogen temperature. Neon was trapped by the cryogenic pump at $40 \mathrm{~K}$ after measuring ${ }^{4} \mathrm{He} /{ }^{20} \mathrm{Ne}$ ratios via online QMS (Pfeiffer Prisma 80). Then, purified helium was injected into a noble gas mass spectrometer (Helix SFT by ThermoFisher) to measure ${ }^{3} \mathrm{He} /{ }^{4} \mathrm{He}$ ratios. Calibration of $\mathrm{He}$ isotope ratios was conducted by using the internal He standard of Japan (HESJ)
[18]. Measured ${ }^{3} \mathrm{He} /{ }^{4} \mathrm{He}$ ratios were corrected for atmospheric helium by using measured ${ }^{4} \mathrm{He} /{ }^{20} \mathrm{Ne}$ ratios, since ${ }^{20} \mathrm{Ne}$ is assumed to be mostly atmospheric [19]. From Sano et al. [20]:

$$
\begin{aligned}
\frac{\mathrm{Rc}}{\mathrm{Ra}} & =\left[\left({ }^{3} \mathrm{He} /{ }^{4} \mathrm{He}\right)_{\text {measured }}-\mathrm{r}\right] /(1-\mathrm{r}) \\
\mathrm{r} & =\left({ }^{4} \mathrm{He} /{ }^{20} \mathrm{Ne}\right)_{\mathrm{AsW}} /\left({ }^{4} \mathrm{He} /{ }^{20} \mathrm{Ne}\right)_{\text {measured }}
\end{aligned}
$$

where $\mathrm{Rc} / \mathrm{Ra}$ is the corrected ${ }^{3} \mathrm{He} /{ }^{4} \mathrm{He}$ ratio, and $\left({ }^{4} \mathrm{He} /{ }^{20} \mathrm{Ne}\right)_{\mathrm{ASW}}$ is the ${ }^{4} \mathrm{He} /{ }^{20} \mathrm{Ne}$ ratio of air-saturated water (ASW). Analytical errors for and ${ }^{3} \mathrm{He} /{ }^{4} \mathrm{He}$ and ${ }^{4} \mathrm{He} /{ }^{20} \mathrm{Ne}$ ratios are about $1 \%$ and $5 \%(1 \sigma)$, respectively. 


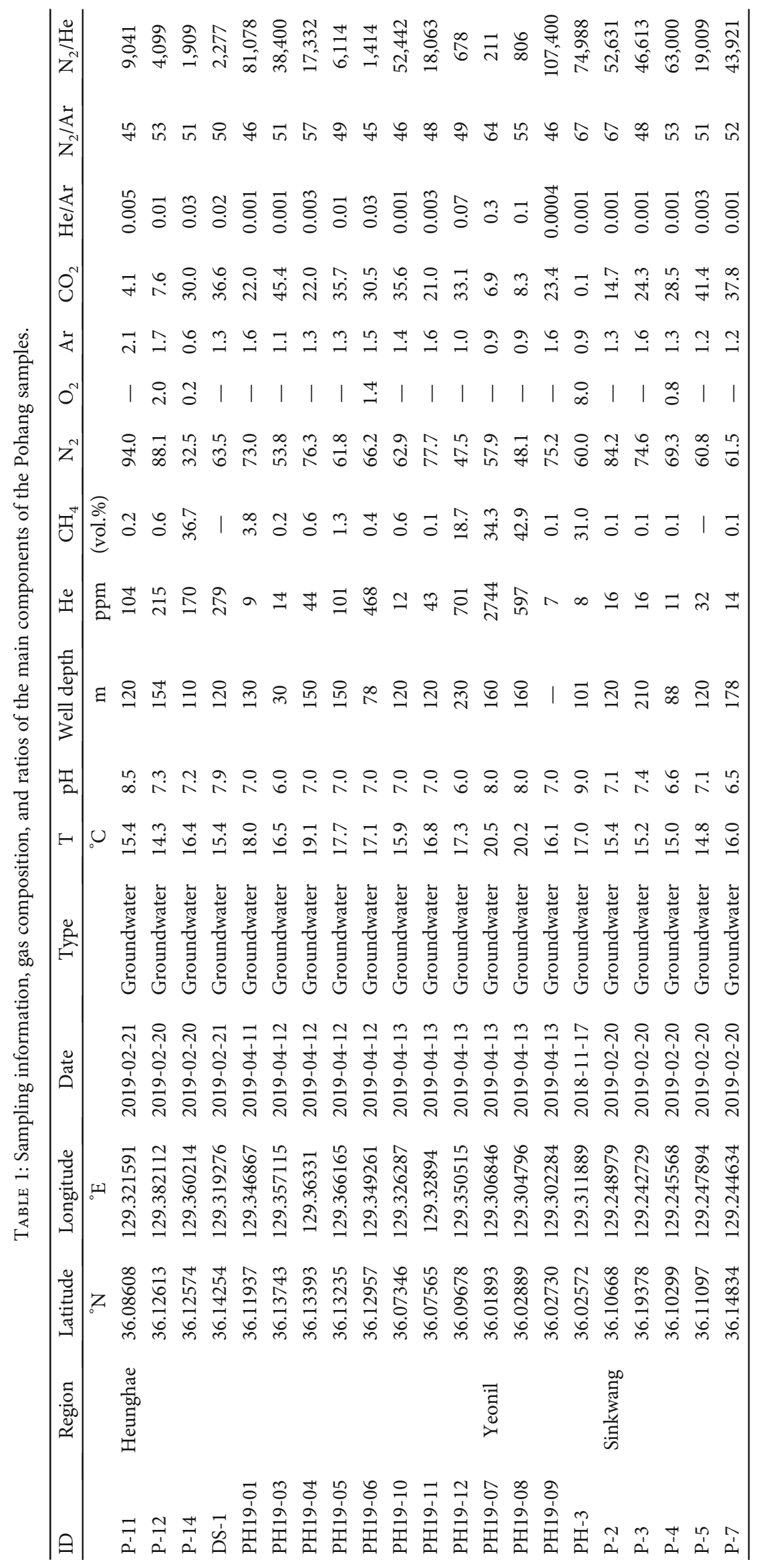




\section{Results}

The measured gas compositions are reported in Table $1 . \mathrm{N}_{2}$ is the most abundant gas component for most samples with the range of 32.5 to $94.0 \mathrm{vol}$ \%. $\mathrm{CO}_{2}$ is also observed in all samples ranging from 0.1 to $45.4 \mathrm{vol} . \% . \mathrm{CH}_{4}$ is also one of the main components for samples in the Heunghae and Yeonil areas (for example, P-14, PH19-12, PH19-07, PH19-08, and $\mathrm{PH}-3$ ) with the range from 18.7 to 42.9 vol.\%. Ar and $\mathrm{He}$ range from 0.6 to 2.1 vol. $\%$ and from 7 to $2744 \mathrm{ppm}$, respectively. Except for PH-3 $\left(\mathrm{O}_{2}=8.0\right.$ vol.\%), almost no $\mathrm{O}_{2}$ is observed in most samples, indicating minimum air contamination during sampling and analysis. Isotopic compositions of $\mathrm{N}, \mathrm{C}$, and He are summarized in Table 2. The nitrogen isotope compositions of $\mathrm{N}_{2}\left(\delta^{15} \mathrm{~N}-\mathrm{N}_{2}\right)$ for all samples range from 0.19 to $3.56 \%$, all heavier than air $(0 \%$ ) . Carbon isotope values of $\mathrm{CO}_{2}\left(\delta^{13} \mathrm{C}-\mathrm{CO}_{2}\right)$ for all samples range from -27.33 to $-16.01 \%$. There is no significant regional difference for $\delta^{15} \mathrm{~N}-\mathrm{N}_{2}$ and $\delta^{13} \mathrm{C}-\mathrm{CO}_{2}$. The carbon isotope composition of $\mathrm{CH}_{4}\left(\delta^{13} \mathrm{C}_{-} \mathrm{CH}_{4}\right)$ is from -76.05 to $-70.04 \%$, implying similar $\mathrm{CH}_{4}$ sources for both Heunghae and Yeonil areas. In these areas, most samples show ${ }^{4} \mathrm{He} /{ }^{20} \mathrm{Ne}$ ratios higher than ASW $\left({ }^{4} \mathrm{He} /{ }^{20} \mathrm{Ne}=0.268,[21]\right)$, with ${ }^{3} \mathrm{He} /{ }^{4} \mathrm{He}$ ratios ranging from 0.18 to $3.83 \mathrm{Ra}$, where $\mathrm{Ra}$ is the ${ }^{3} \mathrm{He} /{ }^{4} \mathrm{He}$ ratio of air $\left(1.4 \times 10^{-6},[22]\right)$. The ${ }^{3} \mathrm{He} /{ }^{4} \mathrm{He}$ ratios $(0.90$ to $1.22 \mathrm{Ra})$ of the Sinkwang groundwater samples are atmospheric because ${ }^{4} \mathrm{He} /{ }^{20} \mathrm{Ne}$ ratios of the samples are similar to air.

\section{Discussion}

4.1. Gas Geochemistry. Based on the $\mathrm{N}_{2}-\mathrm{Ar}-\mathrm{He}$ ternary diagram (Figure 2), nonreactive gases $\left(\mathrm{N}_{2}, \mathrm{Ar}\right.$, and $\left.\mathrm{He}\right)$ in the Heunghae and Yeonil areas display a two-component mixing relationship between the mantle and atmospheric end members. Lee et al. [9] have shown that fault gases in the southeastern Korean peninsula are continental gases rather than subduction zone gases. Dissolved gases in groundwater from the Sinkwang area are atmospheric with low $\mathrm{He} / \mathrm{Ar}$ ratios (0.003 to 0.001). Lee et al. [9] addressed that some gas samples which are severely contaminated by air in southeastern Korea are due to shallow well depths (130 to $296 \mathrm{~m}$ ). However, in the Heunghae and Yeonil areas, it is unlikely that well depths (Table 1) and contribution from deeply derived gases are relevant. Instead, we suggest that distance to the permeable fault zones where gases released from deep sources are transported is important. In general, groundwater wells in the Heunghae and Yeonil areas contain more dissolved helium (Table 2), implying there are more permeable areas than the Sinkwang area.

$\mathrm{CO}_{2}$ concentrations are negatively correlated with $\mathrm{pH}$ $\left(R^{2}=0.62\right)$, indicating that $\mathrm{CO}_{2}$ is likely to be trapped in high $\mathrm{pH}$ water to be present as $\mathrm{HCO}_{3}^{-}$and $\mathrm{CO}_{3}{ }^{2-}$ (Figure S1a, [23, 24]). To verify this, we show that $\mathrm{CO}_{2} / \mathrm{N}_{2}\left(R^{2}=0.61\right)$ and $\mathrm{CO}_{2} / \mathrm{CH}_{4}\left(R^{2}=0.41\right)$ ratios also have negative trends with $\mathrm{pH}$ (Figure S1b, c). It is attributable that $\mathrm{CO}_{2}$ removal increased those ratios because $\mathrm{N}_{2}$ and $\mathrm{CH}_{4}$ are not responsive to $\mathrm{pH}$ changes. Also, $\mathrm{N}_{2}$ and/or $\mathrm{CH}_{4}$-rich gases are found in alkaline springs $[23,25,26]$. Moreover, $\mathrm{CO}_{2} / \mathrm{CH}_{4}$ ratios and helium concentrations show a negative correlation $\left(R^{2}=0.76\right.$, Figure S1d). Although Lee et al. [9] suggested both $\mathrm{CO}_{2}$ and helium are derived from the mantle source in southeastern Korea, it is plausible that their origins are decoupled in the Pohang region.

4.2. Origins of Nitrogen, Carbon Dioxide, and Methane. $\delta$ ${ }^{15} \mathrm{~N}-\mathrm{N}_{2}$ values of all samples with the range of 0.19 to $3.56 \%$ are between the air $(0 \% 0)$ and sediment $(7 \%)$ endmembers. By plotting $\delta^{15} \mathrm{~N}$ with $\mathrm{N}_{2} /{ }^{3} \mathrm{He}$ ratios (Figure 3(a)), we can identify contributions of the air, sediment, and mantle end-members. To quantify the contribution of each end-member, we adopted the three-component mixing model from Sano et al. [27]:

$$
\begin{gathered}
\delta^{15} \mathrm{~N}_{\text {obs }}=\mathrm{f}_{\mathrm{M}} \times \delta^{15} \mathrm{~N}_{\text {mantle }}+\mathrm{f}_{\mathrm{S}} \times \delta^{15} \mathrm{~N}_{\text {sediment }}+\mathrm{f}_{\mathrm{A}} \times \delta^{15} \mathrm{~N}_{\text {air }} \\
\frac{1}{\left(\mathrm{~N}_{2} /{ }^{3} \mathrm{He}\right)_{\text {obs }}}=\frac{\mathrm{f}_{\mathrm{M}}}{\left(\mathrm{N}_{2} /{ }^{3} \mathrm{He}\right)_{\text {mantle }}}+\frac{\mathrm{f}_{\mathrm{S}}}{\left(\mathrm{N}_{2} / /^{3} \mathrm{He}\right)_{\text {sendiment }}}+\frac{\mathrm{f}_{\mathrm{A}}}{\left(\mathrm{N}_{2} /{ }^{3} \mathrm{He}\right)_{\text {air }}} \\
\mathrm{f}_{\mathrm{M}}+\mathrm{f}_{\mathrm{S}}+\mathrm{f}_{\mathrm{A}}=1
\end{gathered}
$$

where obs is the observed value; $f_{M}, f_{S}$, and $f_{A}$ are the contributions of the mantle, sediments, and air; $\delta^{15} \mathrm{~N}_{\text {mantle }}$, $\delta^{15} \mathrm{~N}_{\text {sediment }}$, and $\delta^{15} \mathrm{~N}_{\text {air }}$ are $-5 \pm 2 \%, 7 \pm 4 \%$, and $0 \%$; $\mathrm{N}_{2} /{ }^{3} \mathrm{He}_{\text {mantle }}, \mathrm{N}_{2} /{ }^{3} \mathrm{He}_{\text {sediment }}$, and $\mathrm{N}_{2} /{ }^{3} \mathrm{He}_{\text {air }}$ are $8.9 \times 10^{5}$, $1.4 \times 10^{12}$, and $1.1 \times 10^{11}$, respectively [21, 27, 28, 29 and references therein]. The results are summarized in Table S1. Air is the most dominant source for $\mathrm{N}_{2}$ in the Pohang region with the $\mathrm{f}_{\mathrm{A}}$ range of 49.1 to $97.0 \%$. Also, sediment is another main source for $\mathrm{N}_{2}$ with the $\mathrm{f}_{\mathrm{S}}$ range of 2.8 to $50.9 \%$. The mantle contribution is very minor $\left(\mathrm{f}_{\mathrm{M}}=0\right.$ to $1.0 \%$ ), indicating $\mathrm{N}_{2}$ is the primarily sedimentary origin and is contributed by air at shallow depths. Moreover, the sediment-derived $\mathrm{N}_{2}$ in the Pohang region is of shallow origin rather than the recycled nitrogen through subduction as discussed in section 4.1.

The Pohang region has no mantle-derived $\mathrm{CO}_{2}$ which has been reported in Gyeongju and Ulsan areas, southeastern Korea (Lee et al., 2019). $\delta^{13} \mathrm{C}$ values (-27.33 to $-16.01 \%$ ) of $\mathrm{CO}_{2}$ in all samples are lighter than the MORB value $(-6.5 \pm 2.5 \%$, [30] $)$ and lie approximately between the mean $\delta^{13} \mathrm{C}-\mathrm{CO}_{2}$ values of $\mathrm{C} 3(-27 \%)$ and $\mathrm{C} 4(-13 \%)$ plants [31] (Figure 3(b)). The results are similar to those of most fault gases previously reported in southeastern Korea $\left(\delta^{13} \mathrm{C}-\mathrm{CO}_{2}=-14.50\right.$ to $\left.-24.92 \%\right)$ as well as $\delta^{13} \mathrm{C}-\mathrm{CO}_{2}$ values $(-11.9$ to $-24.0 \%$ ) in global fault zones without magma activity, such as San Andreas Fault and North Anatolian Fault [9 and references therein]. On the $\delta^{13} \mathrm{C}^{-} \mathrm{CO}_{2}$ vs $\mathrm{CO}_{2} /{ }^{3} \mathrm{He}$ plot (Figure S2), a majority of samples are outside the mixing curve between the biogenic and mantle endmembers due to their low $\mathrm{CO}_{2}{ }^{3} \mathrm{He}$ ratios. As discussed in section 4.1, the decrease in $\mathrm{CO}_{2} /{ }^{3} \mathrm{He}$ ratios can be attributed to $\mathrm{CO}_{2}$ loss in this area under the influence of $\mathrm{pH}$. Moreover, the negative correlation $\left(R^{2}=0.88\right)$ between ${ }^{4} \mathrm{He}$ concentrations and $\mathrm{CO}_{2} /{ }^{3} \mathrm{He}$ ratios is displayed well (Figure S1e). Gilfillan et al. [32] have shown the same trend for natural gas fields in North America. They argued that 


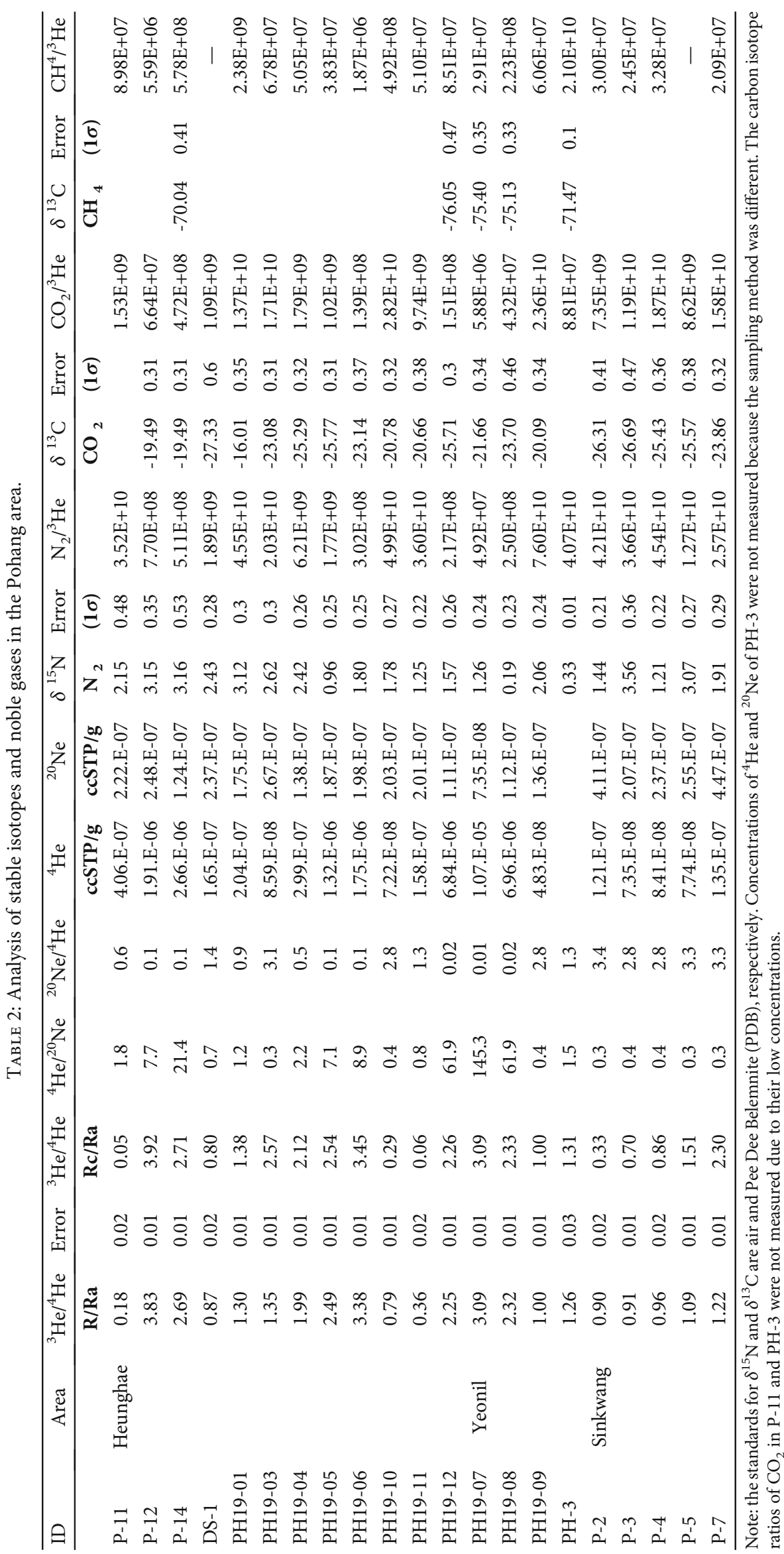




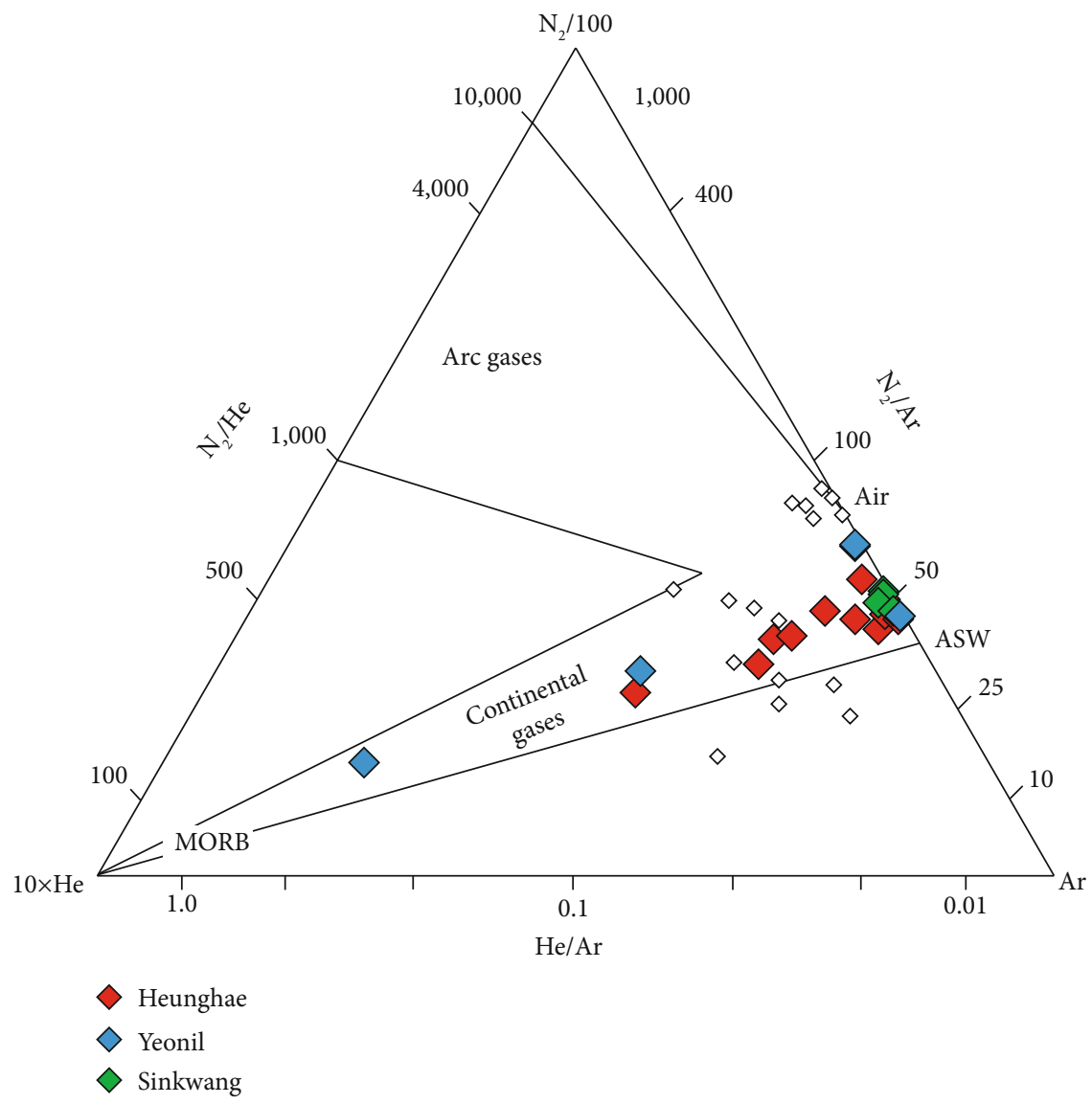

Figure 2: $\mathrm{N}_{2}$-Ar-He ternary plot. Reference data of fault-related gas samples in the southeastern part of the Korean peninsula (white diamond) is shown [9]. All samples are mixed between MORB, air, and air-saturated water (ASW) and displayed as the trend of continental gas.

noble gases are unlikely involved in increasing or decreasing $\mathrm{CO}_{2} /{ }^{3} \mathrm{He}$ ratios. However, the trend between ${ }^{3} \mathrm{He} /{ }^{4} \mathrm{He}$ and $\mathrm{CO}_{2} /{ }^{3} \mathrm{He}$ ratios (Figure S1f) is also negatively correlated $\left(R^{2}=0.54\right)$. Thus, in the Pohang region, we argue that not only $\mathrm{CO}_{2}$ loss but also external helium was introduced to reduce $\mathrm{CO}_{2} /{ }^{3} \mathrm{He}$ ratios in the local groundwater layer (see section 4.3-4.5). This further supports that $\mathrm{CO}_{2}$ source derived from shallower sediments than the mantle.

The origin of $\mathrm{CH}_{4}$ in Pohang is relatively uniform. In the measured samples (Table 2), $\delta^{13} \mathrm{C}$ values of $\mathrm{CH}_{4}$ range from -76.05 to $-70.04 \%$, indicating a typical microbial origin [33]. Considering $\delta^{13} \mathrm{C}$ of $\mathrm{CO}_{2}$, the mechanism of production of $\mathrm{CH}_{4}$ is resulted by carbonate reduction with slight oxidation after the process of methanogenesis (Figure S2b, [34]). Therefore, the isotope separation factors $\left(\varepsilon_{\mathrm{C}} \mathrm{CO}_{2}-\mathrm{CH}_{4}\right)$ which are approximately from 54.36 to 58.12 allow us to estimate the growth temperature of $\mathrm{CH}_{4}$ at $\sim 40^{\circ} \mathrm{C}$ [34].

4.3. Helium Isotope Geochemistry in the Pohang Area. In the Pohang region, higher ${ }^{3} \mathrm{He} /{ }^{4} \mathrm{He}$ ratios (up to $3.83 \mathrm{Ra}$ ) than ASW/air are found in the Heunghae and Yeonil areas. Although elevated ${ }^{3} \mathrm{He} /{ }^{4} \mathrm{He}$ ratios can be resulted by the ${ }^{3} \mathrm{H}$-derived ${ }^{3} \mathrm{He}$, it is unlikely because the samples with high ${ }^{3} \mathrm{He} /{ }^{4} \mathrm{He}$ ratios also have high ${ }^{4} \mathrm{He} /{ }^{20} \mathrm{Ne}$ ratios (up to 145.29). Helium is also remobilized from old igneous rocks [35]. It is known that Pohang Basin is filled by sediments on the granodiorite basement rocks with some Tertiary basaltic rocks (Daljeon basalt) which erupted at $13.8 \mathrm{Ma}$ [14 and references therein]. However, the basaltic rocks show a limited distribution $\left(<1 \mathrm{~km}^{2}\right)$ in the Yeonil area [14 and references therein]. Considering the typical ${ }^{4} \mathrm{He}$ contents in inclusion bearing olivine $\left(10^{-8}\right.$ to $10^{-9}$ ccSTP/g, $[8,35])$ and the ${ }^{4} \mathrm{He}$ concentrations of high ${ }^{3} \mathrm{He} /{ }^{4} \mathrm{He}$ ratio samples from the Yeonil area $\left(1.1 \times 10^{-5}\right.$ to $7.0 \times 10^{-7} \mathrm{ccSTP} / \mathrm{g}$ ), the amounts of trapped ${ }^{3} \mathrm{He}$ in the Daljeon basalt is insufficient to be the source of ${ }^{3} \mathrm{He}$ in the Yeonil area. Furthermore, in consideration of general Li concentration of igneous and sedimentary rock, radiogenic ${ }^{3} \mathrm{He}$ by decay reaction ${ }^{6} \mathrm{Li}(\mathrm{n}, \alpha)^{3} \mathrm{H}(\beta \text { - })^{3} \mathrm{He}$ cannot affect ${ }^{3} \mathrm{He} /{ }^{4} \mathrm{He}$ ratio of groundwater [35 and references therein]. Therefore, the excess ${ }^{3} \mathrm{He}$ in the Pohang region originates from the mantle as well as ${ }^{4} \mathrm{He}[23,36]$.

The range of ${ }^{3} \mathrm{He} /{ }^{4} \mathrm{He}$ ratios $(0.18$ to $3.83 \mathrm{Ra})$ in the Heunghae area is wide, indicating that both mantle and crustal helium sources are present in a short range, up to $10 \mathrm{~km}$ (Figures 1 and 4). Even though some samples (PH19-09 and $\mathrm{PH}-3$ ) in the Yeonil area are atmospheric (Figures 1 and 4), two samples (PH19-07 and PH19-08) 


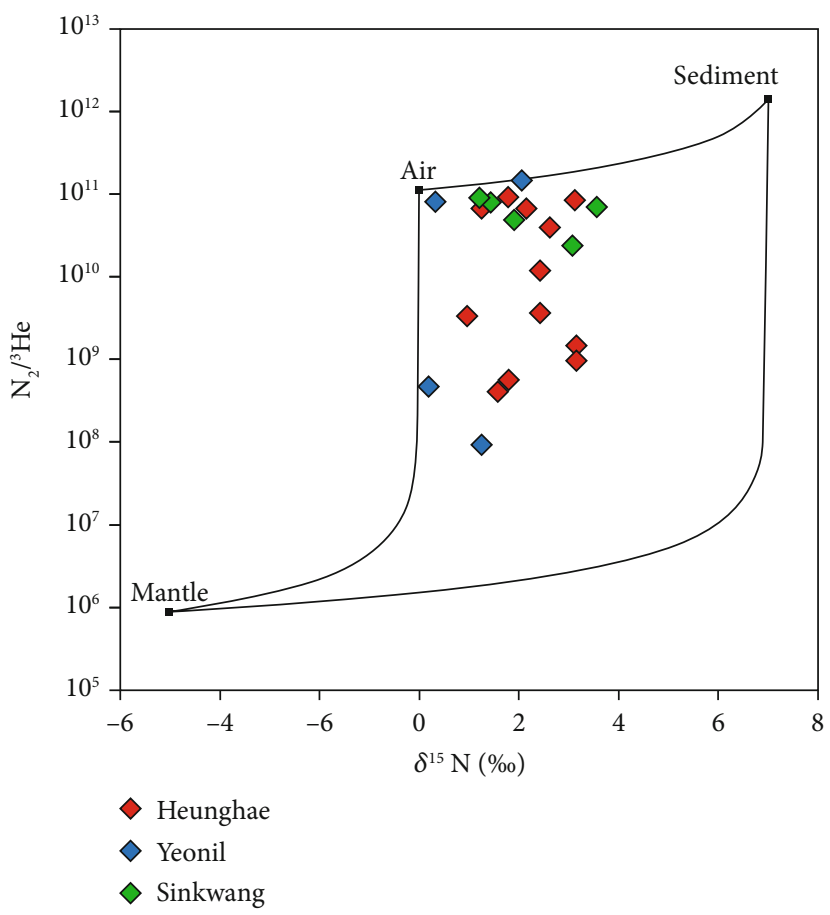

(a)

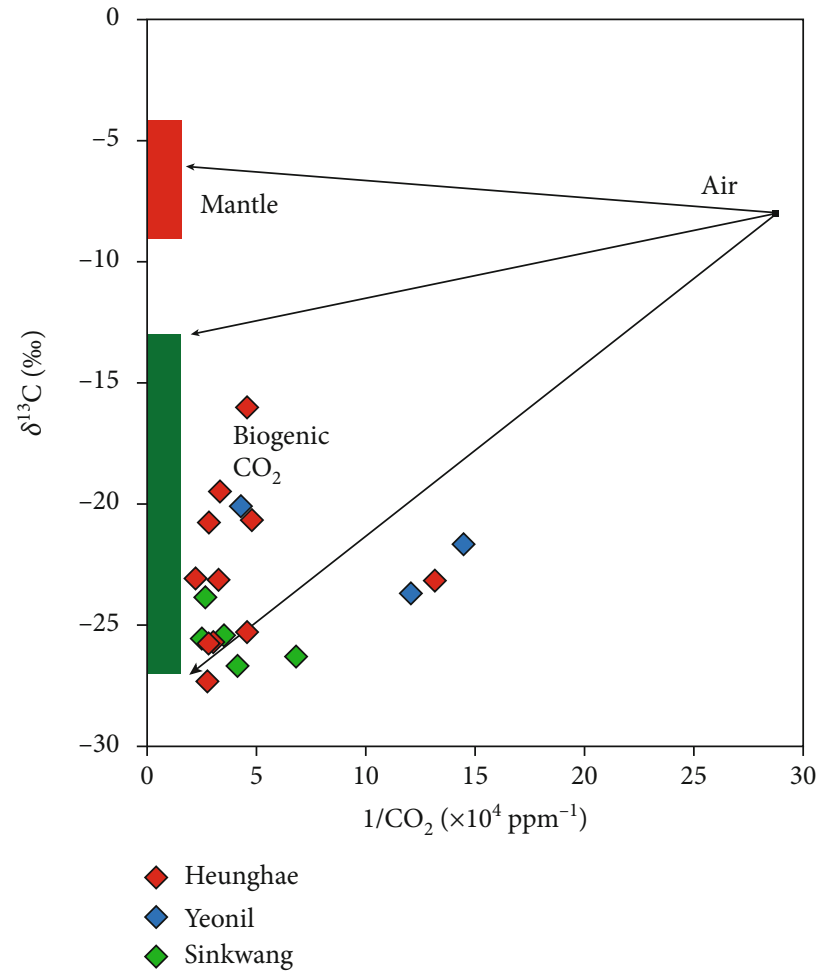

(b)

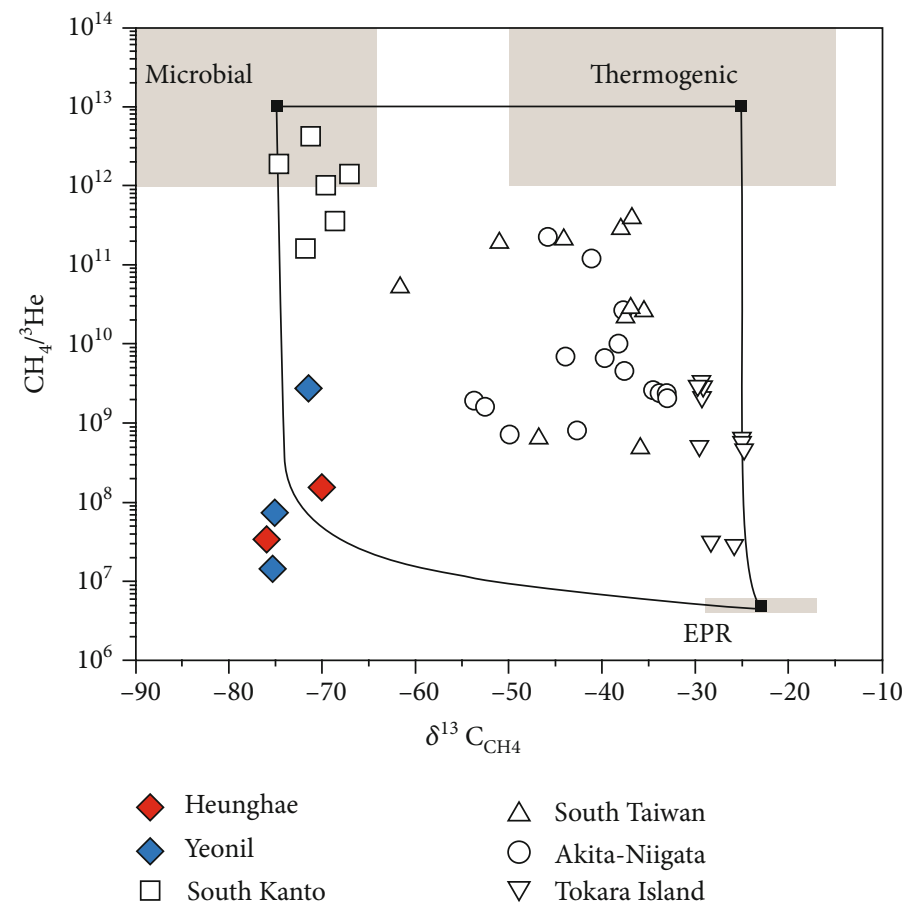

(c)

Figure 3: (a) $\mathrm{N}_{2} /{ }^{3} \mathrm{He}$ versus $\delta^{15} \mathrm{~N}$ diagram. Each end-member and mixing lines are described in section 4.2 . (b) $\delta^{13} \mathrm{C}_{\text {of }} \mathrm{CO}_{2}$ versus $1 / \mathrm{CO}_{2}$ diagram (modified from Lee et al. [53]). Mantle value of $\delta^{13} \mathrm{C}\left(-6.5 \pm 2.5 \%\right.$ ) is from Sano and Marty [30]. The biogenic $\mathrm{CO}_{2}$ area ranges between $\delta^{13} \mathrm{C}$ values of $\mathrm{C} 3$ plant and $\mathrm{C} 4$ plant [31]. The air value of $\delta^{13} \mathrm{C}$ and $\mathrm{CO}_{2}$ concentration are from Lewicki and Brantley [54]. (c) $\mathrm{CH}_{4} /{ }^{3} \mathrm{He}$ versus $\delta^{13} \mathrm{C}$ of $\mathrm{CH}_{4}$ diagram (modified from Sano et al. [55]). Reference data from northeastern Asia is shown together (Sano et al. [55]). 


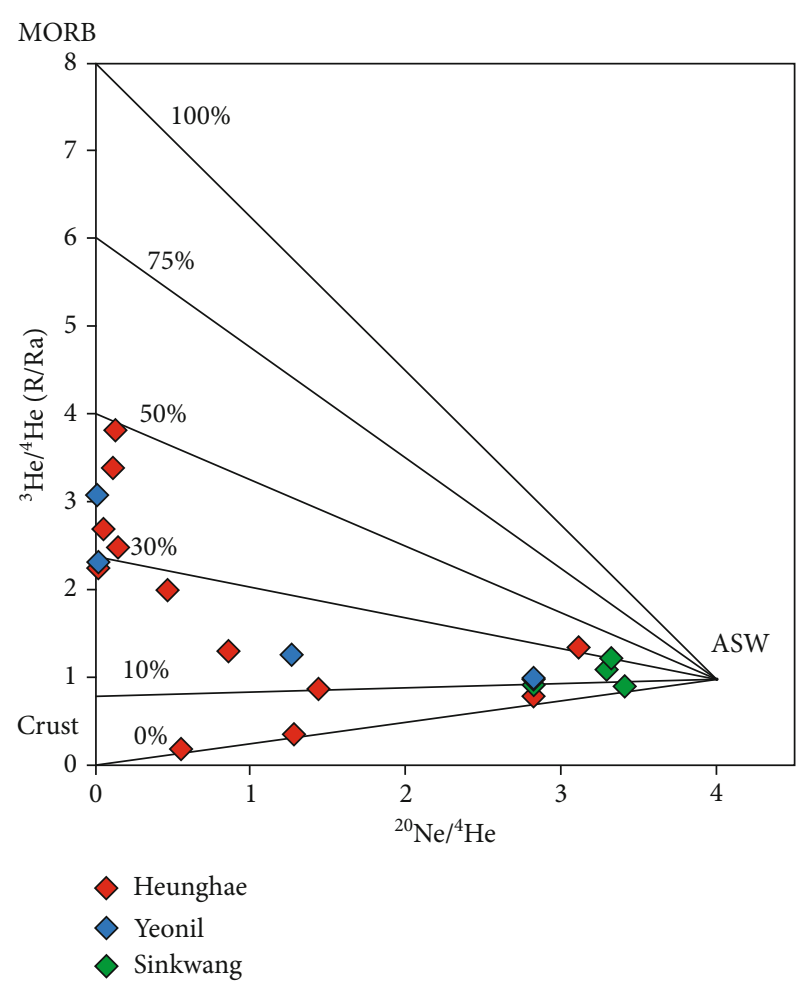

Figure $4:{ }^{3} \mathrm{He} /{ }^{4} \mathrm{He}$ versus ${ }^{20} \mathrm{Ne} /{ }^{22} \mathrm{Ne}$ diagram. The reference values for MORB, ASW, and Crust are shown. Each line represents mixing lines between ASW and external helium sources with different MORB contributions.

have high ${ }^{3} \mathrm{He} /{ }^{4} \mathrm{He}(3.09 \mathrm{Ra}$ and $2.32 \mathrm{Ra})$ and ${ }^{4} \mathrm{He} /{ }^{20} \mathrm{Ne}$ (145.29 and 61.86) ratios, implying the presence of mantle-derived fluids. All samples in the Sinkwang area show atmospheric ${ }^{3} \mathrm{He} /{ }^{4} \mathrm{He}(0.90-1.34 \mathrm{Ra})$ and ${ }^{4} \mathrm{He} /{ }^{20} \mathrm{Ne}$ (0.27-0.36) ratios (Figures 1 and 4$) . \mathrm{A}{ }^{3} \mathrm{He} /{ }^{4} \mathrm{He}$ ratio of up to $5.69 \mathrm{Ra}$ was reported for the Yangsan fault zones [9]. The absence of mantle signatures for all samples in the Sinkwang area can be explained by the distance from the main fault line (Figure 1), which means the influx of external helium is quite low.

The highest ${ }^{3} \mathrm{He} /{ }^{4} \mathrm{He}$ ratio $(3.83 \mathrm{Ra}$ ) represents about $50 \%$ of the mantle contribution to the fluid (Figure 4 ). It is known that mantle-derived helium can be actively released to the surface through magmatism $[37,38]$. However, the Pohang region is located hundreds of kilometers away from the active volcanoes of the Japanese arc (Figure 1). A low-velocity zone beneath Ulleungdo has been proposed by Chen et al. [39] and references therein, which is also $200 \mathrm{~km}$ away from Pohang. Moreover, magma activity in this area has been ceased after 9,300 6,300 BP [40 and references therein].

The appropriate model for the occurrence of mantlederived helium in this region is that there are permeable fault zones like the release of mantle fluids in the San Andreas Fault zones [5]. According to Song [14], there are some faults in the Pohang region, such as Heunghae, Gokgang, Hyeongsan, and Ocheon faults (Figure 1). Also, Westaway and Burnside [41] named the new fault as the Namsong fault on the basis of the aftershock distribution of the Pohang earthquake
(Figure 1) and proposed that the fault has been already critically stressed before the EGS project [41]. In addition, according to the Korea Meteorological Administration (KMA), the depths of the 2017 Pohang earthquake and aftershocks are less than $16 \mathrm{~km}$, which is shallower than the Moho depth $(\sim 28 \mathrm{~km})$ of the region [42]. Kennedy and Van Soest [37] suggested that the mantle fluids of the San Andreas Fault penetrate the brittle-ductile boundary based on helium isotope ratios and strain rates measured by GPS. To explain the mantle-derived helium in the Gyeongju and Ulsan areas, southeastern Korea, Lee et al. [9] also proposed that mantle helium migrates along the ductile shear zone underneath the brittle regime.

From the above information, in the Pohang region, we suggest that there have been already tectonically active areas that have developed from the ductile shear zone to the brittle fault zone. This condition enabled the inflow of the mantlederived fluids through the lower crust into the permeable faults. Furthermore, in this area, relatively high temperatures, heat contents, and heat flows have been reported [ 43 and references therein], supporting that ${ }^{3} \mathrm{He}$ came from the mantle through active faults (e.g., Umeda et al. [44]).

4.4. Distribution of Active Faults. As discussed in section 4.3, we identified the existence of permeable faults in the Heunghae and Yeonil areas. The locations of the faults can be constrained based on the geographical distribution of helium isotope ratios [7]. Since the latitude variation in the ${ }^{3} \mathrm{He} /{ }^{4} \mathrm{He}$ ratios is the most prominent to specify fault locations, we can show the relationship between the ${ }^{3} \mathrm{He} /{ }^{4} \mathrm{He}$ ratios and latitude (Figure S3). Although it is known that the location of the Heunghae fault is still ambiguous, we found that the distribution of higher ${ }^{3} \mathrm{He} /{ }^{4} \mathrm{He}$ ratios are well consistent with the fault striking $\mathrm{EW}$ at $36.126^{\circ} \mathrm{N}$ (Figure 1). Also, there is a relationship between higher ${ }^{3} \mathrm{He} /{ }^{4} \mathrm{He}$ ratios and distance from the fault line (Figure 5(a)), which has been observed in the San Andreas, North Anatolian, and Karakoram faults $[5,8,37,45]$. In Figure 5(a), we could observe a sample ( $\mathrm{PH} 19-12)$ with a high ${ }^{3} \mathrm{He} /{ }^{4} \mathrm{He}$ ratio $(2.25 \mathrm{Ra})$, which is about $3 \mathrm{~km}$ away from the Heunghae fault to the south (Figures 1, S3). The sampling location of PH19-12 is still in the area where aftershocks have frequently occurred (Figure 1), suggesting there can be another ${ }^{3} \mathrm{He}$ discharge in the Heunghae area. To confirm the pathway of mantle-derived helium, we calculated the distance of all samples from the Namsong fault (Figure 5(b)). Based on the mainshock strike $\left(\mathrm{N} 34^{\circ} \mathrm{E}\right)$ and $\operatorname{dip}\left(51^{\circ} \mathrm{NW}\right)$, we assumed that the easternmost boundary of the aftershock occurrences (from 2017 Annual report of Earthquake) with the $\mathrm{N} 34^{\circ} \mathrm{E}$ strike is the uppermost line of the fault. By using this uppermost line, the distance from the closest fault and ${ }^{3} \mathrm{He} /{ }^{4} \mathrm{He}$ ratios are displayed (Figure 5(c)), showing a better correlation with exponential distribution $\left(R^{2}=0.80\right)$ than Figure $5(\mathrm{a})$. To validate the relationship between the distance from faults and ${ }^{3} \mathrm{He} /{ }^{4} \mathrm{He}$ ratios, we selected six samples at latitudes higher than P12 (Figure 5(a), red circles). These samples are well correlated with distance from the Heunghae fault exponentially $\left(R^{2}=0.98\right)$, validating the model of the Heunghae- 


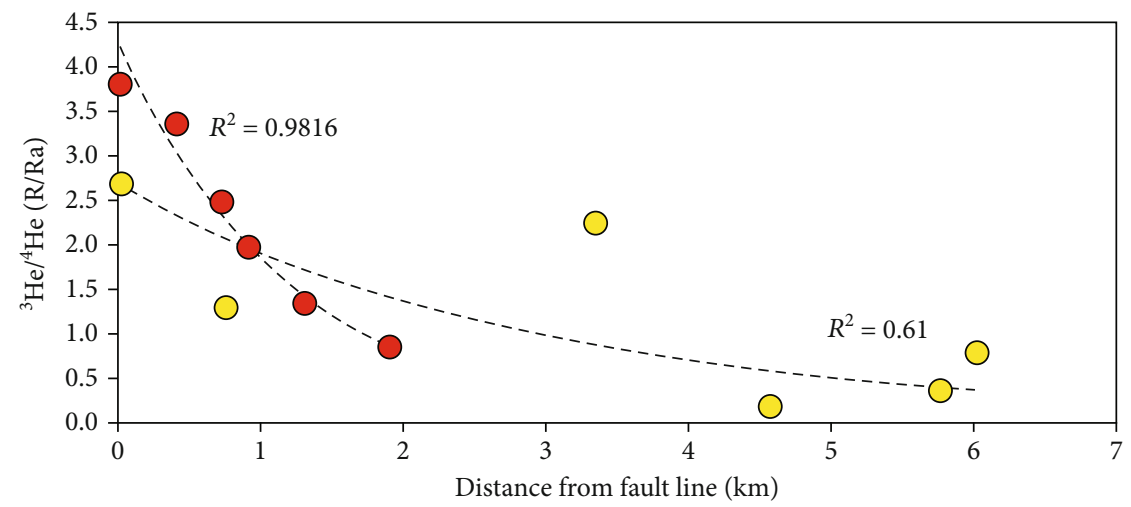

(a)

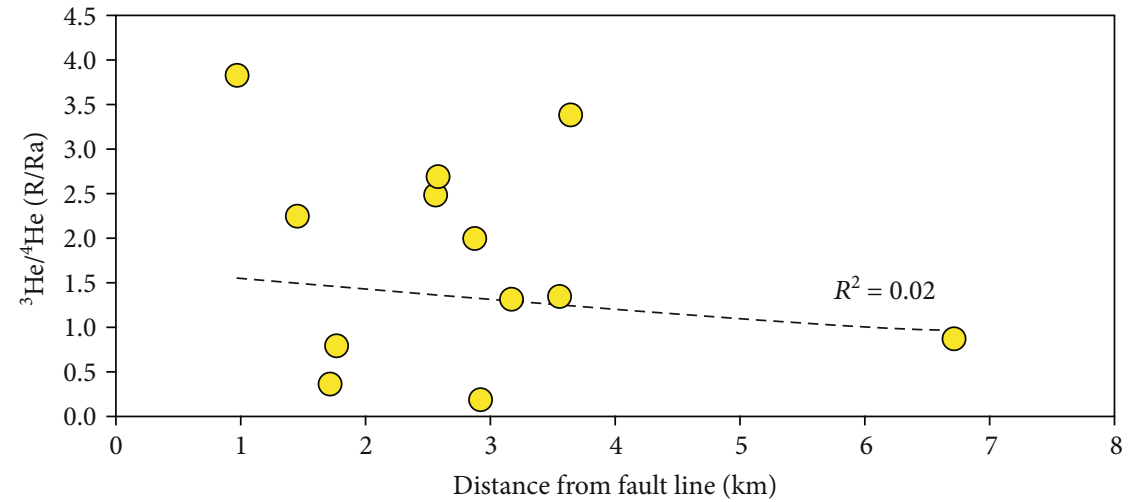

(b)

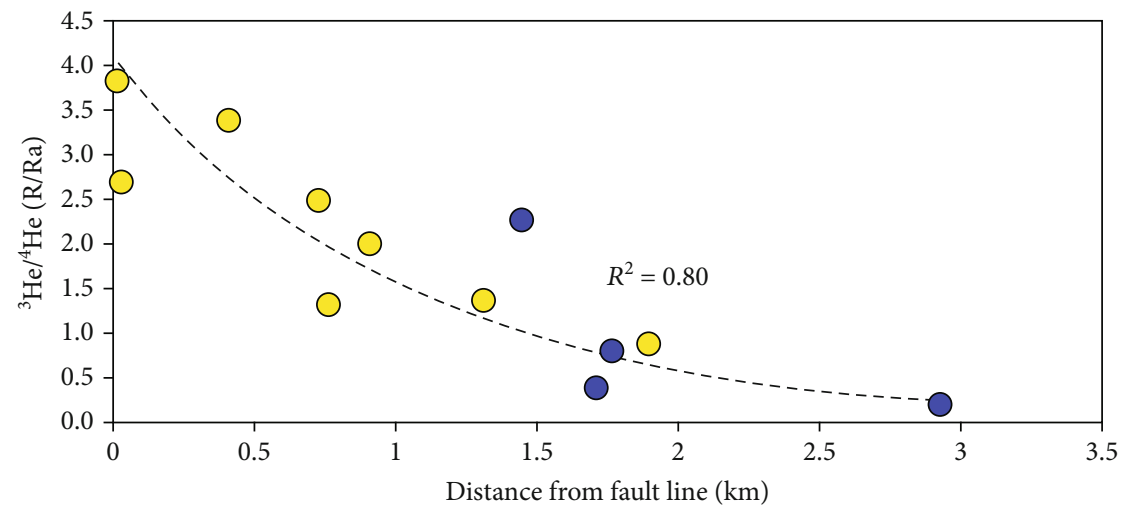

(c)

Figure 5: (a) ${ }^{3} \mathrm{He} /{ }^{4} \mathrm{He}$ ratios to distance from the Heunghae fault line. Samples at latitudes higher than P-12 are marked with red circles. (b) ${ }^{3} \mathrm{He} /{ }^{4} \mathrm{He}$ ratios to distance from the Namsong fault line, which is not prominent. (c) ${ }^{3} \mathrm{He} /{ }^{4} \mathrm{He}$ ratios to distance from closer fault lines between the Heunghae and Namsong fault lines. Samples closer to the Namsong fault than the Heunghae fault are marked with blue circles.

Namsong fault system as shown in Figure 5(c). Samples with lower ${ }^{3} \mathrm{He} /{ }^{4} \mathrm{He}$ ratios than $1 \mathrm{Ra}$ indicate that the inflow of ${ }^{3} \mathrm{He}$ into the aquifer is less than crustal or atmospheric contributions (Figure 4). Although it is not well known about the exact fault locations in the Yeonil area, previous studies have reported the presence of faults [14 and references therein]. Based on some samples with high ${ }^{3} \mathrm{He} /{ }^{4} \mathrm{He}$ ratios (Figure 1), we suggest that there can be a highly permeable fault zone. In this study, we propose to name the Jamyeong fault considering the name of the village called Jamyeong-ri in this area.
4.5. Helium Flux from the Faults. To compare fluid dynamics with other fault systems in the world, helium flow rates and ${ }^{3} \mathrm{He}$ flux were estimated. We calculated helium flow rates from the most reliable mantle helium source from each fault (P-12 for Heunghae fault, $\mathrm{PH} 19-07$ for Jamyeong fault, PH19-12 for Namsong fault), following Menzies et al. [46]:

$$
q H e=\frac{H_{c} \rho_{c} P(H e)}{\rho_{f}[H e]_{F . m}} \times\left[\frac{R_{s}-R_{c}}{R_{m}-R_{s}}\right]
$$


where $q H e$ is the helium flow rate $(\mathrm{cm} / \mathrm{yr}) ; H c$ is the crust thickness; $\rho c$ and $\rho f$ are the density of the crust and the fluid, respectively; $P(\mathrm{He})$ is the current production rate of ${ }^{4} \mathrm{He}$ from crust; $[\mathrm{He}] \mathrm{F} . \mathrm{m}$ is the concentration of helium in the original mantle fluid; $R s, R c$, and $R m$ represent helium isotopic ratios $\left({ }^{3} \mathrm{He} /{ }^{4} \mathrm{He}\right)$ of the sample, crust, and mantle, respectively. The crust below the Pohang region was assumed to be a double layer with thicknesses for the upper and middle crust of 12.3 and $15.6 \mathrm{~km}$, respectively $[42,47]$. We used the average density values of the middle crust $\left(2.72 \mathrm{~g} / \mathrm{cm}^{3}\right)$ and the upper crust $\left(2.65 \mathrm{~g} / \mathrm{cm}^{3}\right)$ as $\rho c$ and the water density $\left(1 \mathrm{~g} / \mathrm{cm}^{3}\right)$ as $\rho f$ [48 and references therein]. From Menzies et al. [46], $\mathrm{P}(\mathrm{He})\left(\mathrm{ccSTP} \mathrm{g}^{-1} \mathrm{yr}^{-1}\right)$ can be obtained as:

$\mathrm{P}(\mathrm{He})=\rho_{\mathrm{c}} \times\left(1.19 \times 10^{-13} \times[\mathrm{U}]+2.88 \times 10^{-14} \times[\mathrm{Th}]\right) \times(1-\Phi) / \Phi$

where ${ }^{4} \mathrm{He}$ production rates of $\mathrm{U}$ and Th are $1.19 \times 10^{-13}$ ccSTP $\mu \mathrm{g}^{-1} \mathrm{yr}^{-1}$ and $2.88 \times 10^{-14} \operatorname{ccSTP} \mu \mathrm{g}^{-1} \mathrm{yr}^{-1}$, respectively; $[U]$ and $[T h]$ are concentrations for $U$ and $T h$ in ppm; $\Phi$ is the porosity of the material. By using the average concentration of each layer for $\mathrm{U}$ (middle crust: $0.7 \mathrm{ppm}$ and upper crust: $2.7 \mathrm{ppm}$ ) and Th (middle crust: $0.63 \mathrm{ppm}$ and upper crust: $10.5 \mathrm{ppm}$ ) [48 and references therein], $\mathrm{H}_{c} \rho_{c} \mathrm{P}(\mathrm{He})$ for each crust layer (in equation (3)) was calculated and were added all up. The $[\mathrm{He}]_{\text {F.m }}$ for each sample was calculated using Rs $(0.02 \mathrm{Ra}), \mathrm{Rm}$ (8 Ra), and helium concentration of each sample.

Each variable is measured or obtained except $\Phi$, resulting in that the helium flow rate is a function of porosity $(\Phi)$. The porosity of Yeongnam Massif granodiorite underneath the study area is $0.48 \%$ [49]. The porosity measured by wireless logging along PX2 at depth is 5.2\% [49], which includes the void volume of fractures. The porosity of the fault zone itself should be higher than that of the fractured basement rock. Therefore, we assumed four different porosity conditions with $\Phi=0.01,0.05,0.1$, and 0.2 which are about $0.2,1,2$, and 4 times the porosity of the basement rock.

Calculated helium flow rates $(\mathrm{qHe})$ for a given porosity range from $26.95 \mathrm{~cm} / \mathrm{yr}$ to $128 \mathrm{~cm} / \mathrm{yr}$ (Heunghae fault), $5.34 \mathrm{~cm} / \mathrm{yr}$ to $25.37 \mathrm{~cm} / \mathrm{yr}$ (Namsong fault), and $4.00 \mathrm{~cm} / \mathrm{yr}$ to $19.02 \mathrm{~cm} / \mathrm{yr}$ (Jamyeong fault, Table S2). Compared with other global fault zones (1.7 to $12.7 \mathrm{~cm} / \mathrm{yr}$ of San Andreas Fault; $0.87 \mathrm{~cm} / \mathrm{yr}$ of North Anatolian Fault; $55 \mathrm{~cm} / \mathrm{yr}$ of Alpine Fault, New Zealand) $[46,50]$, faults in the Pohang region show relatively high helium flow rates. To assume that faults in the Pohang region have helium flows of the approximately same magnitude, the porosity of the faults need to be higher than other fault systems. Thus, in the fault zones of the Pohang region, it is believed that the porosity is high, or the helium flow rate is high. With the calculated helium flow rates and measured helium concentration of each sample, we were able to calculate the ${ }^{3} \mathrm{He}$ flux for each sample site by using measured ${ }^{3} \mathrm{He} /{ }^{4} \mathrm{He}$ ratios. The ${ }^{3} \mathrm{He}$ flux per unit area $\left(\Phi^{3} \mathrm{He}\right)$ can be calculated as:

$$
\Phi^{3} \mathrm{He}=\mathrm{qHe} \times \rho \mathrm{f} \times\left[{ }^{4} \mathrm{He}\right] \times \mathrm{R}
$$

where $\left[{ }^{4} \mathrm{He}\right]$ is measured ${ }^{4} \mathrm{He}$ concentration of each sample; $R$ is helium isotopic composition $\left({ }^{3} \mathrm{He} /{ }^{4} \mathrm{He}\right)$. The calculated ${ }^{3} \mathrm{He}$ flux values are 120 to 3,000 atoms $\mathrm{cm}^{-2} \mathrm{sec}^{-1}$ (Heunghae fault), 52 to 1,300 atoms $\mathrm{cm}^{-2} \mathrm{sec}^{-1}$ (Namsong fault), and 83 to 2,100 atoms $\mathrm{cm}^{-2} \mathrm{sec}^{-1}$ (Jamyeong fault, Table S2).

In Figure 6, samples related to the Heunghae fault show the correlation between ${ }^{3} \mathrm{He}$ flux and fault. Considering the size of the study area $(<10 \mathrm{~km}$ from the fault), this trend can be compared with the results near the Futagawa fault $(<40 \mathrm{~km}$ from the fault) in the Kumamoto area, Kyushu, Japan, where an earthquake of magnitude 7.3 occurred on April 16, 2016 (Sano et al. [6], Table S3, Figure 7). The Heunghae fault zone shows the sharper pattern than the Futagawa fault zone because samples from this area are collected in a smaller area. The maximum flux of the Futagawa fault is 5,600 atoms $\mathrm{cm}^{-2} \mathrm{sec}^{-1}$, which is higher than that of the Heunghae area because the sample is close to the fault as well as Mt Aso to supply helium from the nearby magma [6].

Like the helium flow rate, this ${ }^{3} \mathrm{He}$ flux is relatively high compared to other major fault systems, such as 1.7 to 34 atoms $\mathrm{cm}^{-2} \mathrm{sec}^{-1}$ of the San Andreas Fault, 75 atoms cm ${ }^{2} \mathrm{sec}^{-1}$ of the North Anatolian Fault, and 170 atoms $\mathrm{cm}^{-}$ ${ }^{2} \mathrm{sec}^{-1}$ of the Alpine Fault, New Zealand [46, 50], showing high porosity in the fault zone or high ${ }^{3} \mathrm{He}$ flux per unit area (Figure 7). Also, this ${ }^{3} \mathrm{He}$ flux is several orders of magnitude higher than the continental ${ }^{3} \mathrm{He}$ flux in steady-state (3.9 to 7.2 atoms $\mathrm{cm}^{-2} \mathrm{sec}^{-1}$, from Sano et al. [51]). Therefore, the helium flux results suggest that the Pohang region may have faults comparable to other active fault zones around the world (Figures 1, 6).

\section{Conclusions}

We first analyzed dissolved gases in groundwater in the Pohang region, South Korea, where the Mw 5.5 earthquake occurred on November 15, 2017. The $\mathrm{N}_{2}$-Ar-He relationship shows that there is the contribution of the mantle component in the Heunghae and Yeonil area samples, which is similar to that previously reported in fault zones of the southeastern Korean peninsula [9]. However, the dissolved gases in the Sinkwang area are mostly close to atmospheric components. $\mathrm{N}_{2}$ (32. 5 to 94.0 vol.\%) and $\mathrm{CO}_{2}$ (0.1 to 45.4 vol.\%) are present in all areas of the Pohang region, and $\mathrm{CH}_{4}$ (18.7 to 42.9 vol.\%) is observed as a major component in some samples of the Heunghae and Yeonil areas. The results of the stable isotope analysis indicate that $\mathrm{N}_{2}$ $\left(\delta^{15} \mathrm{~N}=0.2\right.$ to $\left.3.6 \%\right), \mathrm{CO}_{2}\left(\delta^{13} \mathrm{C}=-27.3\right.$ to $\left.-16.0 \%\right)$, and $\mathrm{CH}_{4}\left(\delta^{13} \mathrm{C}=-76.1\right.$ to $-70.0 \%$ ) in the Pohang region are derived from organic material sources at shallow depths. Helium isotope ratios $\left({ }^{3} \mathrm{He} /{ }^{4} \mathrm{He}\right)$ with mantle signatures (up to $3.83 \mathrm{Ra}$ ) are observed in the Heunghae and Yeonil areas except in the Sinkwang area, where atmospheric ${ }^{3} \mathrm{He} /{ }^{4} \mathrm{He}$ ratios are mainly observed. Helium originates from the mantle, but the Pohang region, a sedimentary basin formed during the Miocene period, is believed to contain a large amount of organic matter that can be the source for $\mathrm{N}_{2}, \mathrm{CO}_{2}$, and 


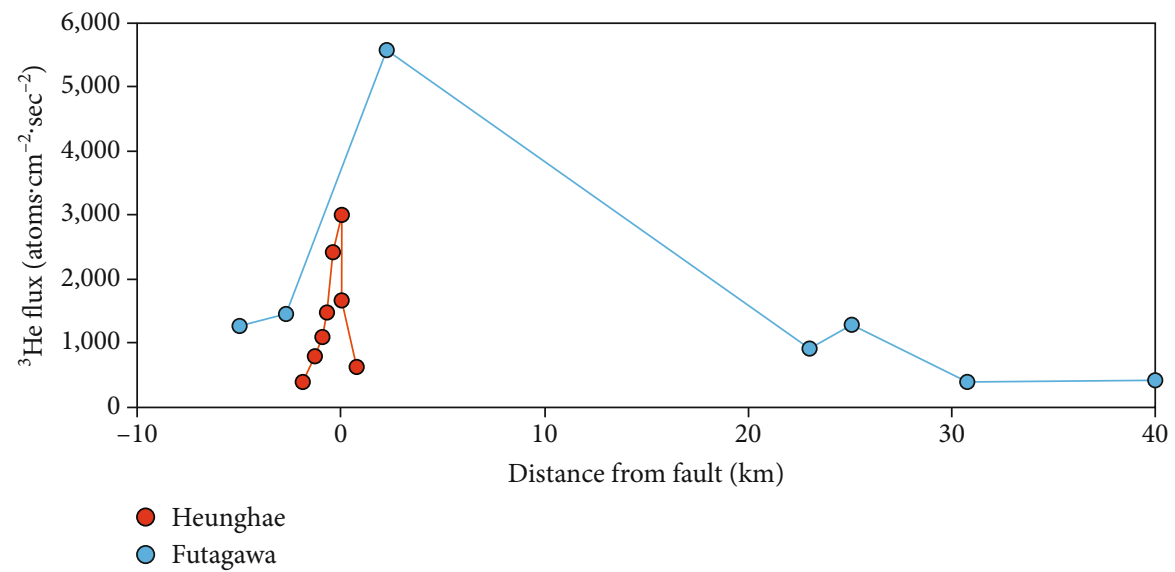

Figure 6: ${ }^{3} \mathrm{He}$ flux values displayed according to the distance from the Heunghae fault in the Pohang region (this study) and the Futagawa fault in the Kumamoto region, Japan [6]. The assumptions about the calculations are described in section 4.5.

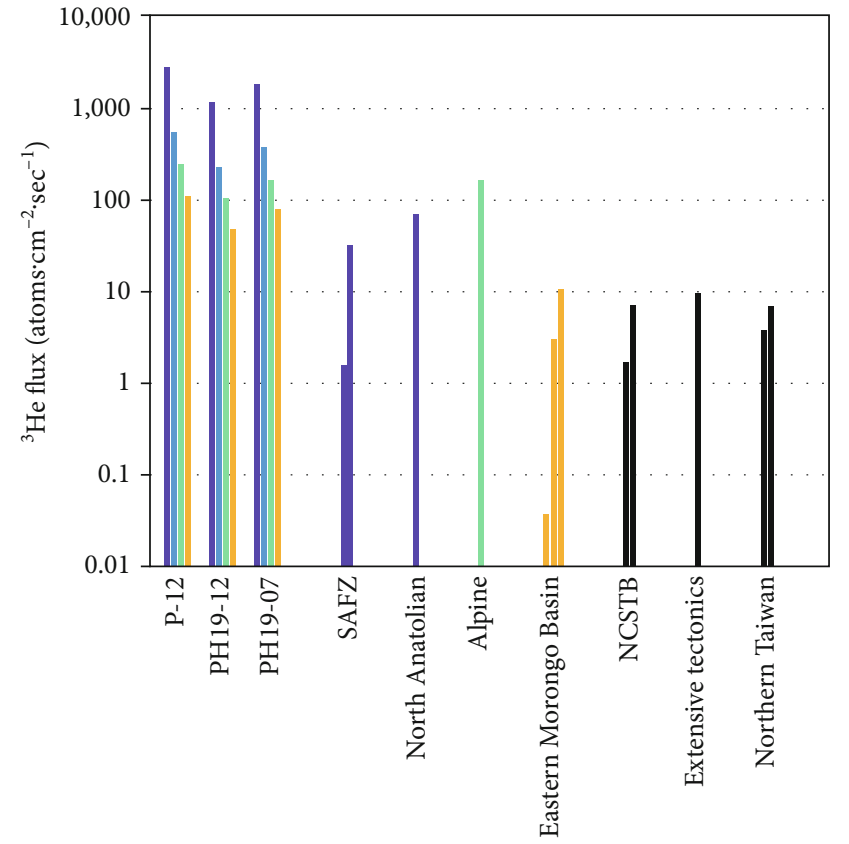

Figure 7: ${ }^{3} \mathrm{He}$ flux of the Heunghae (P-12), Namsong (PH19-12), and Jamyeong faults (PH19-07). Reference data from San Andreas Fault Zone (SAFZ, [50]), North Anatolian Fault[50], Alpine Fault [46], Eastern Morogongo basin [56], North-Central Sicilly thermal basin (NCStb) [57], extensive tectonics settings [22], and Northern Taiwan [51].

$\mathrm{CH}_{4}$. The distribution of the helium isotope ratio seems to be related to the locations of faults which are permeable passage. Based on the observation, we suggest that the Heunghae, Namsong, and Jamyeong faults in the Pohang region are active faults that release the mantle fluids. Although the Heunghae and Namsong faults are close to the EGS facilities,

considering the depths $(<10 \mathrm{~km})$ of the 2017 earthquake and aftershocks in the area, the Moho depth $(\sim 28 \mathrm{~km})$ is far below, which is similar to the Gyeongju and Ulsan areas [9]. Thus, we propose that there were already active faults extending into the ductile shear zone to release the mantle helium. In order to show that the faults in this area are active, we computed ${ }^{3} \mathrm{He}$ flux $\left(\Phi^{3} \mathrm{He}\right)$ for the Heunghae (120 to 3,000 atoms $\mathrm{cm}^{-2} \mathrm{sec}^{-1}$ ), Namsong (52 to 1,300 atoms $\mathrm{cm}^{-}$ ${ }^{2} \mathrm{sec}^{-1}$ ), and Jamyeong (83 to 2,100 atoms $\mathrm{cm}^{-2} \mathrm{sec}^{-1}$ ) faults. These values are comparable to those in the regions known as active faults around the world, which may be due to either high porosity or high helium flow rates. Therefore, our results demonstrate that there are active faults in Pohang, especially around the EGS facilities, and will provide important information for future research.

\section{Data Availability}

All the data in this study is contained in the tables of both the main manuscript and the Supplementary Materials.

\section{Conflicts of Interest}

The authors declare that there is no conflict of interest regarding the publication of this paper.

\section{Acknowledgments}

This study was financially supported by the fundamental research project of Korea Institute of Geoscience and Mineral resources (KIGAM) and the National Research Foundation of Korea (NRF) grant funded by the Korea government (MSIT) (NRF-2019R1G1A1002297). We are grateful to Myungok Jung and Kwangtae Kim for their support on the sampling.

\section{Supplementary Materials}

Figure S1: (a) relative concentration of $\mathrm{CO}_{2}$ and $\mathrm{pH}$ plot. (b) $\mathrm{CO}_{2} / \mathrm{N}_{2}$ and $\mathrm{pH}$ plot. (c) $\mathrm{CO}_{2} / \mathrm{CH}_{4}$ and $\mathrm{pH}$ plot. (d) 
$\mathrm{CO}_{2} / \mathrm{CH}_{4}$ and concentration of ${ }^{4} \mathrm{He}$ plot. (e) $\mathrm{CO}_{2} /{ }^{3} \mathrm{He}$ and concentration of ${ }^{4} \mathrm{He}$ plot. (f) $\mathrm{CO}_{2} /{ }^{3} \mathrm{He}$ and ${ }^{3} \mathrm{He} /{ }^{4} \mathrm{He}$ ratio plot. Figure S2: (a) $\mathrm{CO}_{2} /{ }^{3} \mathrm{He}$ and $\delta^{13} \mathrm{C}$ plot. Dashed arrow indicates $\mathrm{CO}_{2} /{ }^{3} \mathrm{He}$ and $\delta^{13} \mathrm{C}$ decrease trend due to $\mathrm{CO}_{2}$ trap, which described in Section 4.2. (b) $\delta^{13} \mathrm{C}$ of $\mathrm{CO}_{2}$ and $\delta^{13} \mathrm{C}$ of $\mathrm{CH}_{4}$ plot (modified from Wfhiticar [34]). Figure S3: helium samples from the Heunghae area (diamond symbol) and the helium isotope and latitude plot. Each symbol is colored by its helium isotope ratio $\left({ }^{3} \mathrm{He} /{ }^{4} \mathrm{He}\right)$. The locations of Heunghae (HF) and Namsong (NF) fault lines (dashed line) are described in Section 4.4. The gray triangle indicates the location of the EGS site, and the brown star indicates the location of the $\mathrm{Mw} 5.5$ earthquake. Table S1: $\delta^{15} \mathrm{~N}, \mathrm{~N}_{2} /{ }^{3} \mathrm{He}$, and the contribution of three nitrogen endmembers on the Pohang samples: the mantle, sediment, and the air. The $\delta^{15} \mathrm{~N}$ and $\mathrm{N}_{2} /{ }^{3} \mathrm{He}$ of each endmember and the mixing model are described in Section 4.2. Table S2: the corrected Helium isotope ratio, the concentration of helium in original mantle fluid, the helium flow rate, and the ${ }^{3} \mathrm{He}$ flux of each fault system. Table S3: the ${ }^{4} \mathrm{He}$ concentration, corrected ${ }^{3} \mathrm{He} /{ }^{4} \mathrm{He}$ ratio, and ${ }^{3} \mathrm{He}$ flux of each sample and their distance from related faults, respectively. The data of the Futagawa fault is from Sano et al. [6]. (Supplementary Materials)

\section{References}

[1] E. L. Majer, R. Baria, M. Stark et al., "Induced seismicity associated with Enhanced Geothermal Systems," Geothermics, vol. 36, no. 3, pp. 185-222, 2007.

[2] K. M. Keranen, H. M. Savage, G. A. Abers, and E. S. Cochran, "Potentially induced earthquakes in Oklahoma, USA: links between wastewater injection and the $2011 \mathrm{Mw} 5.7$ earthquake sequence," Geology, vol. 41, no. 6, pp. 699-702, 2013.

[3] A. McGarr, D. Simpson, and L. Seeber, Case Histories of Induced and Triggered Seismicity, in: International Handbook of Earthquake and Engineering Seismology, Academic Press LTD, 2002.

[4] Z. E. Ross, B. Idini, Z. Jia et al., "Hierarchical interlocked orthogonal faulting in the 2019 Ridgecrest earthquake sequence," Science, vol. 366, no. 6463, pp. 346-351, 2019.

[5] B. M. Kennedy, "Mantle fluids in the San Andreas fault system, California," Science, vol. 278, no. 5341, pp. 1278-1281, 1997.

[6] Y. Sano, N. Takahata, T. Kagoshima, T. Shibata, T. Onoue, and D. Zhao, "Groundwater helium anomaly reflects strain change during the 2016 Kumamoto earthquake in Southwest Japan," Scientific Reports, vol. 6, no. 1, 2016.

[7] K. Umeda and A. Ninomiya, "Helium isotopes as a tool for detecting concealed active faults," Geochemistry, Geophysics, Geosystems, vol. 10, no. 8, 2009.

[8] S. L. Klemperer, B. M. Kennedy, S. R. Sastry, Y. Makovsky, T. Harinarayana, and M. L. Leech, "Mantle fluids in the Karakoram fault: helium isotope evidence," Earth and Planetary Science Letters, vol. 366, pp. 59-70, 2013.

[9] H. Lee, H. Kim, T. Kagoshima, J.-O. Park, N. Takahata, and Y. Sano, "Mantle degassing along strike-slip faults in the Southeastern Korean Peninsula," Scientific Reports, vol. 9, no. 1, article 15334, 2019.

[10] S. K. Chough, S.-T. Kwon, J.-H. Ree, and D. K. Choi, “Tectonic and sedimentary evolution of the Korean peninsula: a review and new view," Earth-Science Reviews, vol. 52, no. 1-3, pp. 175-235, 2000.

[11] J.-M. Kim, "Early Neogene biochemostratigraphy of Pohang Basin: a paleoceanographic response to the early opening of the Sea of Japan (East Sea)," Marine Micropaleontology, vol. 36, no. 4, pp. 269-290, 1999.

[12] S. Yi and H. Yun, "Miocene calcareous nannoplankton from the Pohang Basin, Korea," Palaeontographica Abteilung B, vol. 237, pp. 113-158, 1995.

[13] T. J. Lee, Y. Song, D.-W. Park, J. Jeon, and W. S. Yoon, “Three dimensional geological model of Pohang EGS pilot site, Korea," Proceedings of the World Geothermal Congress, vol. 19, pp. 19-25, 2015.

[14] C. W. Song, Study on the Evolution of the Miocene Pohang Basin Based on its Structural Characteristics, Pusan National University, Busan, Korea, 2015, (In Korean with English abstract).

[15] S. S. Chun and S. K. Chough, "Tectonic history of Crataceous sedimentary basins in the southwestern Korean Peninsula and Yellow Sea," The Sedimentary Basins in the Korean Peninsula and Adjacent Seas, pp. 60-76, 1992.

[16] D. W. Lee, "Strike-slip fault tectonics and basin formation during the Cretaceous in the Korean Peninsula," Island Arc, vol. 8, no. 2, pp. 218-231, 1999.

[17] K. K. Lee, "Summary report of the Korean government commission on relations between the 2017 Pohang earthquake and EGS project," The Geological Society of Korea, 2019.

[18] J. Matsuda, T. Matsumoto, H. Sumino et al., "The ${ }^{3} \mathrm{He} /{ }^{4} \mathrm{He}$ ratio of the new internal He Standard of Japan (HESJ)," Geochemical Journal, vol. 36, no. 2, pp. 191-195, 2002.

[19] H. Craig, W. B. Clarke, and M. A. Beg, "Excess ${ }^{3}$ He in deep water on the East Pacific Rise," Earth and Planetary Science Letters, vol. 26, no. 2, pp. 125-132, 1975.

[20] Y. Sano, N. Takahata, and T. Seno, "Geographical distribution of ${ }^{3} \mathrm{He} /{ }^{4} \mathrm{He}$ ratios in the Chugoku District, Southwestern Japan," Pure and Applied Geophysics, vol. 163, no. 4, pp. 745-757, 2006.

[21] Y. Sano and H. Wakita, "Geographical distribution of ${ }^{3} \mathrm{He} /{ }^{4} \mathrm{He}$ ratios in Japan: implications for arc tectonics and incipient magmatism," Journal of Geophysical Research: Solid Earth, vol. 90, no. B10, pp. 8729-8741, 1985.

[22] M. Ozima and F. A. Podosek, Noble Gas Geochemistry, Cambridge University Press, 2002.

[23] H. Lee, T. P. Fischer, J. D. Muirhead et al., "Incipient rifting accompanied by the release of subcontinental lithospheric mantle volatiles in the Magadi and Natron basin, East Africa," Journal of Volcanology and Geothermal Research, vol. 346, pp. 118-133, 2017.

[24] J. Zhang, P. D. Quay, and D. O. Wilbur, "Carbon isotope fractionation during gas-water exchange and dissolution of $\mathrm{CO}_{2}$," Geochimica et Cosmochimica Acta, vol. 59, no. 1, pp. 107-114, 1995.

[25] K. Suda, Y. Ueno, M. Yoshizaki et al., "Origin of methane in serpentinite-hosted hydrothermal systems: the $\mathrm{CH}_{4}-\mathrm{H}_{2}-\mathrm{H}_{2} \mathrm{O}$ hydrogen isotope systematics of the Hakuba Happo hot spring," Earth and Planetary Science Letters, vol. 386, pp. 112-125, 2014.

[26] Y. Taran, D. Morán-Zenteno, S. Inguaggiato, N. Varley, and L. Luna-González, "Geochemistry of thermal springs and geodynamics of the convergent Mexican Pacific margin," Chemical Geology, vol. 339, pp. 251-262, 2013. 
[27] Y. Sano, N. Takahata, Y. Nishio, T. P. Fischer, and S. N. Williams, "Volcanic flux of nitrogen from the Earth," Chemical Geology, vol. 171, no. 3-4, pp. 263-271, 2001.

[28] B. Marty, "Nitrogen content of the mantle inferred from $\mathrm{N}_{2}-$ Ar correlation in oceanic basalts," Nature, vol. 377, no. 6547, pp. 326-329, 1995.

[29] B. Marty and L. Zimmermann, "Volatiles (He, C, N, Ar) in mid-ocean ridge basalts: assesment of shallow- level fractionation and characterization of source composition," Geochimica et Cosmochimica Acta, vol. 63, no. 21, pp. 3619-3633, 1999.

[30] Y. Sano and B. Marty, "Origin of carbon in fumarolic gas from island arcs," Chemical Geology, vol. 119, no. 1-4, pp. 265-274, 1995.

[31] W. Cheng, "Measurement of rhizosphere respiration and organic matter decomposition using natural ${ }^{13} \mathrm{C}$," Plant and Soil, vol. 183, no. 2, pp. 263-268, 1996.

[32] S. M. V. Gilfillan, C. J. Ballentine, G. Holland et al., "The noble gas geochemistry of natural $\mathrm{CO}_{2}$ gas reservoirs from the Colorado Plateau and Rocky Mountain provinces, USA," Geochimica et Cosmochimica Acta, vol. 72, no. 4, pp. 1174-1198, 2008.

[33] M. Schoell, "The hydrogen and carbon isotopic composition of methane from natural gases of various origins," Geochimica et Cosmochimica Acta, vol. 44, no. 5, pp. 649-661, 1980.

[34] M. J. Whiticar, "Carbon and hydrogen isotope systematics of bacterial formation and oxidation of methane," Chemical Geology, vol. 161, no. 1-3, pp. 291-314, 1999.

[35] L. Hoke, S. Lamb, D. R. Hilton, and R. J. Poreda, "Southern limit of mantle-derived geothermal helium emissions in Tibet: implications for lithospheric structure," Earth and Planetary Science Letters, vol. 180, no. 3-4, pp. 297-308, 2000.

[36] T. Torgersen, "Continental degassing flux of ${ }^{4} \mathrm{He}$ and its variability," Geochemistry, Geophysics, Geosystems, vol. 11, no. 6, 2010.

[37] B. M. Kennedy and M. C. van Soest, "Flow of mantle fluids through the ductile lower crust: helium isotope trends," Science, vol. 318, no. 5855, pp. 1433-1436, 2007.

[38] Y. Sano, Y. Nakamura, H. Wakita, A. Urabe, and T. Tominaga, "Helium-3 emission related to volcanic activity," Science, vol. 224, no. 4645, pp. 150-151, 1984.

[39] C. Chen, D. Zhao, Y. Tian et al., "Mantle transition zone, stagnant slab and intraplate volcanism in Northeast Asia," Geophysical Journal International, vol. 209, no. 1, pp. 68-85, 2017.

[40] K. B. Kim and G. D. Lee, "A study on volcanic stratigraphy and fault of Ulleung-do, Korea," The Journal of Engineering Geology, vol. 18, no. 3, pp. 321-330, 2008, (In Korean with English abstract).

[41] R. Westaway and N. M. Burnside, "Fault "corrosion" by fluid injection: a potential cause of the November $2017 M_{W} 5.5$ Korean earthquake," Geofluids, vol. 2019, Article ID 1280721, 23 pages, 2019.

[42] T. W. Chung, M. Z. Iqbal, Y. Lee, K. Yoshimoto, and J. Jeong, "Depth-dependent seismicity and crustal heterogeneity in South Korea," Tectonophysics, vol. 749, pp. 12-20, 2018.

[43] T.-K. Hong, S. Park, and S. E. Houng, "Seismotectonic properties and zonation of the far-eastern Eurasian plate around the Korean Peninsula," Pure and Applied Geophysics, vol. 173, no. 4, pp. 1175-1195, 2016.

[44] K. Umeda, Y. Sakagawa, A. Ninomiya, and K. Asamori, "Relationship between helium isotopes and heat flux from hot springs in a non-volcanic region, Kii Peninsula, southwest Japan," Geophysical Research Letters, vol. 34, no. 5, pp. 1-5, 2007.

[45] T. Doğan, H. Sumino, K. Nagao, K. Notsu, M. K. Tuncer, and C. Çelik, "Adjacent releases of mantle helium and soil $\mathrm{CO}_{2}$ from active faults: Observations from the Marmara region of the North Anatolian Fault zone, Turkey," Geochemistry, Geophysics, Geosystems, vol. 10, no. 11, 2009.

[46] C. D. Menzies, D. A. H. Teagle, S. Niedermann et al., "The fluid budget of a continental plate boundary fault: quantification from the Alpine Fault, New Zealand," Earth and Planetary Science Letters, vol. 445, pp. 125-135, 2016.

[47] K. Y. Kim, J. M. Lee, W. Moon, C. E. Baag, H. Jung, and M. H. Hong, "Crustal structure of the southern Korean peninsula from seismic waves generated by large explosions in 2002 and 2004," Pure and Applied Geophysics, vol. 164, no. 1, pp. 97-113, 2007.

[48] B. R. Hacker, P. B. Kelemen, and M. D. Behn, "Continental lower crust," Annual Review of Earth and Planetary Sciences, vol. 43, no. 1, pp. 167-205, 2015.

[49] S. Kwon, L. Xie, S. Park et al., "Characterization of 4.2-kmdeep fractured granodiorite cores from Pohang Geothermal Reservoir, Korea," Rock Mechanics and Rock Engineering, vol. 52, no. 3, pp. 771-782, 2019.

[50] J. T. Kulongoski, D. R. Hilton, P. H. Barry, B. K. Esser, D. Hillegonds, and K. Belitz, "Volatile fluxes through the Big Bend section of the San Andreas Fault, California: helium and carbon-dioxide systematics," Chemical Geology, vol. 339, pp. 92-102, 2013.

[51] Y. Sano, H. Wakita, and C. W. Huang, "Helium flux in a continental land area estimated from ${ }^{3} \mathrm{He} /{ }^{4} \mathrm{He}$ ratio in northern Taiwan," Nature, vol. 323, no. 6083, pp. 55-57, 1986.

[52] W. B. F. Ryan, S. M. Carbotte, J. O. Coplan et al., "Global multi-resolution topography synthesis," Geochemistry, Geophysics, Geosystems, vol. 10, no. 3, 2009.

[53] H. Lee, J. D. Muirhead, T. P. Fischer et al., "Massive and prolonged deep carbon emissions associated with continental rifting," Nature Geoscience, vol. 9, no. 2, pp. 145-149, 2016.

[54] J. L. Lewicki and S. L. Brantley, " $\mathrm{CO}_{2}$ degassing along the San Andreas Fault, Parkfield, California," Geophysical Research Letters, vol. 27, no. 1, pp. 5-8, 2000.

[55] Y. Sano, N. Kinoshita, T. Kagoshima et al., "Origin of methane-rich natural gas at the West Pacific convergent plate boundary," Scientific Reports, vol. 7, no. 1, article 15646, 2017.

[56] J. T. Kulongoski, D. R. Hilton, and J. A. Izbicki, "Source and movement of helium in the eastern Morongo groundwater Basin: the influence of regional tectonics on crustal and mantle helium fluxes," Geochimica et Cosmochimica Acta, vol. 69, no. 15, pp. 3857-3872, 2005.

[57] A. Caracausi and A. Sulli, "Outgassing of mantle volatiles in compressional tectonic regime away from volcanism: the role of continental delamination," Geochemistry, Geophysics, Geosystems, vol. 20, no. 4, pp. 2007-2020, 2019. 